\title{
Characterisation of an elective course on climate change for health professional students
}

\author{
Ereca Nguyen, Hugo Aguilar, Yaser Khoshal, Conan MacDougall iD, Katherine Gruenberg iD \\ School of Pharmacy, University of California, San Francisco, USA
}

\author{
Keywords \\ Climate change \\ Curriculum \\ Environmental health \\ Education \\ Pharmacy
}

\section{Correspondence}

Katherine Gruenberg

Assistant professor of clinical pharmacy

Department of Clinical Pharmacy

School of Pharmacy

University of California

San Francisco

533 Parnassus Avenue

Katherine.Gruenberg@ucsf.edu

\begin{abstract}
Context: A 10-week elective course, designed by students and supported by faculty, was developed to raise awareness about climate change and health among graduate health professional students. This article aims to characterise the course design, implementation, and student feedback gathered over three years. Description of Course: Course topics aligned with United Nations General Assembly Sustainable Development Goals and were sequenced to first introduce students to basic climate change concepts, followed by examples of human activities with environmental and health consequences. Speakers held diverse roles in health care, research, public health organisations, and advocacy groups. Students evaluated both individual speakers and the course. Evaluation: 152 health professional students enrolled in the course over 3 years. The course was well-received with favourable speaker ratings and course evaluations across all years. Students commented on the importance and relevance of the course topics taught by a diverse group of speakers. Students also requested examples of ways to address climate health issues. Future plans: A 10-week elective course on climate change and health, designed by students and supported by faculty, resulted in favourable evaluations among health professions students. The authors plan to conduct an assessment of student knowledge gained from the course and delayed assessments of students' attitudes and behaviours to evaluate changes over time and achievement of course goals.
\end{abstract}

\section{Context}

Healthcare and climate change are inextricably linked. Extreme weather events due to climate change can lead to significant health-related morbidity and mortality, especially among vulnerable populations (Levy \& Patz, 2015; Crimmins et al., 2016; Watts et al., 2019). Healthcare systems, which contribute an estimated $4.6 \%$ of global emissions, may further exacerbate the impacts of climate on health (Watts et al., 2019). Educating health professional students on these topics may encourage awareness of climaterelated health consequences and sustainable healthcare practices. Calls for instruction on climate change within pharmacy, nursing, and medical education support these educational goals (International Pharmaceutical Federation, 2016; Leffers et al., 2017; Shaman \& Knowlton, 2018; Teherani et al.,
2018; Cook et al., 2019; Mercer, 2019). However, few educational curricula addressing climate change and healthcare are published to date (Richardson et al., 2014; Gruenberg et al., 2017;). Additionally, to the authors' knowledge, the literature lacks descriptions of dedicated courses on climate change offered to students across different health professions students.

In November 2013, University of California (UC) President Janet Napolitano announced the Carbon Neutrality Initiative (CNI), which aims for the ten UC campuses to achieve net-zero greenhouse gas emissions by 2025. As part of this initiative, the CNI Student Fellowship Program was created to encourage student participation in advancing the UC system's carbon neutrality and sustainability goals. From 20172019, three pharmacy students from the UC San Francisco (UCSF) School of Pharmacy were awarded a 
CNI Fellowship to design and implement an elective course about climate change and health at the UCSF health sciences campus. Herein this article aims to characterise the course design, implementation, and student feedback gathered over three years.

\section{Description of course}

The CNI Fellows developed a 10-week, 1-unit elective course for health professional students enrolled in UCSF, which offers programs in pharmacy, medicine, dentistry, physical therapy, nursing, and graduate division programs (for example, biomedical sciences). At UCSF, courses can only have one instructor of record. A School of Pharmacy faculty member (CM in 2017, KG in 2018 and 2019) served as the CNI Fellowship mentor and the instructor of record. The UCSF Office of the Registrar, Department of Clinical Pharmacy Chair, School of Pharmacy Curriculum Committee, School of Pharmacy Dean, UCSF Committee on Courses of Instruction Chair, and an Interprofessional Education representative reviewed the course description, objectives and unit calculation prior to approving the course.

With oversight from the instructor of record, the CNI Fellows led the course design, topic selection, speaker recruitment, and implementation. The course was offered once weekly for one hour during the Spring Academic Quarter (April to June) for three consecutive academic years between 2017 and 2019. Students were eligible to enrol once. The course, entitled Earth Health: Sustainability in Health Care, aimed to enhance foundational knowledge about climate change and shape attitudes among health professional students. The long-term goal of the course was for students to apply principles of sustainability into their professional practice.

Course topics were sequenced to first introduce students to basic climate change concepts, followed by examples of human activities with environmental and health consequences; these issues were discussed both on a local and global level to illustrate the magnitude of climate change and the disproportionate impacts on vulnerable populations globally. After establishing foundational knowledge in climate change and healthcare, relevant proposed legislation (for example, carbon tax) and activist efforts were discussed to promote an actionable approach to climate change. Topics aligned with the UC Carbon Neutrality Initiative goals and the United Nations General Assembly Sustainable Development Goals (Table I). The CNI fellows and instructor of record identified speakers through networking connections within and outside
UCSF. In addition to their professional roles as clinicians, researchers, and public health directors, many speakers held leadership roles in organisations, such as Physicians for Social Responsibility, The Public Health Institute, Citizen's Climate Lobby, and The Science and Environmental Health Network. As both healthcare professionals and advocates, these speakers modelled the application of sustainability within their careers.

Table I: Course topics mapped to United Nations General Assembly Sustainable Development Goals

\begin{tabular}{|c|c|c|}
\hline $\begin{array}{l}\text { Course } \\
\text { years } \\
\text { presented } \\
\end{array}$ & Course topics & $\begin{array}{l}\text { United Nations General } \\
\text { Assembly Sustainable } \\
\text { Development Goals }\end{array}$ \\
\hline 2017 & $\begin{array}{l}\text { Climate change } \\
\text { and health equity }\end{array}$ & $\begin{array}{l}\text { Goal 3: Good health and well- } \\
\text { being } \\
\text { Goal 13: Climate action }\end{array}$ \\
\hline 2017 & $\begin{array}{l}\text { Sugar industry } \\
\text { and } \\
\text { environmental } \\
\text { economics }\end{array}$ & $\begin{array}{l}\text { Goal 7: Affordable and clean } \\
\text { energy } \\
\text { Goal 12: Responsible } \\
\text { consumption and production }\end{array}$ \\
\hline $\begin{array}{l}2017 \\
2018\end{array}$ & $\begin{array}{l}\text { Sustainable food } \\
\text { practices }\end{array}$ & $\begin{array}{l}\text { Goal 2: Zero hunger } \\
\text { Goal 12: Responsible } \\
\text { consumption and production }\end{array}$ \\
\hline $\begin{array}{l}2017 \\
2018\end{array}$ & $\begin{array}{l}\text { Carbon tax \& } \\
\text { citizen lobbying }\end{array}$ & $\begin{array}{l}\text { Goal 7: Affordable and clean } \\
\text { energy } \\
\text { Goal 13: Climate action }\end{array}$ \\
\hline $\begin{array}{l}2017 \\
2018 \\
2019\end{array}$ & $\begin{array}{l}\text { Earth friendly } \\
\text { nutrition }\end{array}$ & $\begin{array}{l}\text { Goal 2: Zero hunger } \\
\text { Goal 12: Responsible } \\
\text { consumption and production }\end{array}$ \\
\hline $\begin{array}{l}2017 \\
2018 \\
2019\end{array}$ & $\begin{array}{l}\text { Sustainability at } \\
\text { UCSF }\end{array}$ & $\begin{array}{l}\text { Goal 7: Affordable and clean } \\
\text { energy } \\
\text { Goal 11: Sustainable cities } \\
\text { and communities } \\
\text { Goal 13: Climate action }\end{array}$ \\
\hline $\begin{array}{l}2017 \\
2018 \\
2019\end{array}$ & $\begin{array}{l}\text { Sustainable } \\
\text { prescribing and } \\
\text { managing } \\
\text { medication waste }\end{array}$ & $\begin{array}{l}\text { Goal 3: Good health and well- } \\
\text { being } \\
\text { Goal 11: Sustainable cities } \\
\text { and communities }\end{array}$ \\
\hline $\begin{array}{l}2017 \\
2018 \\
2019\end{array}$ & $\begin{array}{l}\text { Climate change } \\
\text { and health }\end{array}$ & $\begin{array}{l}\text { Goal 3: Good health and well- } \\
\text { being } \\
\text { Goal 11: Sustainable cities } \\
\text { and communities }\end{array}$ \\
\hline $\begin{array}{l}2017 \\
2018 \\
2019\end{array}$ & $\begin{array}{l}\text { Health } \\
\text { professional } \\
\text { activism }\end{array}$ & $\begin{array}{l}\text { Goal 3: Good health and well- } \\
\text { being } \\
\text { Goal 13: Climate action }\end{array}$ \\
\hline $\begin{array}{l}2017 \\
2018 \\
2019\end{array}$ & $\begin{array}{l}\text { Climate action } \\
\text { and activism }\end{array}$ & $\begin{array}{l}\text { Goal 11: Sustainable cities } \\
\text { and communities } \\
\text { Goal 13: Climate action }\end{array}$ \\
\hline 2018 & $\begin{array}{l}\text { Hydraulic } \\
\text { fracturing }\end{array}$ & $\begin{array}{l}\text { Goal 7: Affordable and clean } \\
\text { energy } \\
\text { Goal 12: Responsible } \\
\text { consumption and production }\end{array}$ \\
\hline $\begin{array}{l}2018 \\
2019\end{array}$ & $\begin{array}{l}\text { Environmental } \\
\text { and respiratory } \\
\text { health }\end{array}$ & $\begin{array}{l}\text { Goal 3: Good health and well- } \\
\text { being } \\
\text { Goal 12: Responsible } \\
\text { consumption and production }\end{array}$ \\
\hline 2019 & $\begin{array}{l}\text { Meat, health, and } \\
\text { the environment }\end{array}$ & $\begin{array}{l}\text { Goal 12: Responsible } \\
\text { consumption and production }\end{array}$ \\
\hline 2019 & $\begin{array}{l}\text { Climate change } \\
\text { activism: Clinician } \\
\text { perspective }\end{array}$ & $\begin{array}{l}\text { Goal 3: Good health and well- } \\
\text { being } \\
\text { Goal 13: Climate action }\end{array}$ \\
\hline
\end{tabular}


Enrolled students were required to attend each class and complete a weekly speaker evaluation to successfully pass the course. The $\mathrm{CNI}$ fellows and course instructor developed the speaker evaluation, which were administered via an online survey using Qualtrics (Provo, UT). Students were asked to anonymously rate each presenter on a 10-point scale (where ten is ideal). Students were also invited to complete an overall course evaluation at the end of the academic quarter. Course evaluation questions are standardised across all UCSF School of Pharmacy courses and are administered online using the course evaluation system $E^{*}$ value (MedHub; Minneapolis, $M N)$. The course evaluation included three Likert questions that asked students to rate their agreement on a 5-point scale [strongly disagree (1), disagree (2), undecided (3), agree (4), strongly agree (5)] with the following statements: 1) The course was wellorganised; 2) The course allowed for sufficient student participation and interaction with the instructor(s); and 3) The course lectures, activities, and assignments helped the student to learn the material. The course evaluation also included one open-ended question requesting feedback for the course. These evaluation questions have previously been validated within the UCSF School of Pharmacy and deemed appropriate for all courses. Individual speaker evaluations and overall course evaluations were reviewed by the course director and CNI Fellows annually to evaluate student perceptions and plan adjustments for the following year. Each report included descriptive analyses of student ratings. Qualitative comments were analysed for common themes using Dedoose Version 7.0.23 (SocioCultural Research Consultants, Los Angeles, CA). In accordance with UCSF Institutional Review Board (IRB) recommendations, IRB review was not required since teaching evaluations were designed and evaluated to inform the quality improvement of the course (UCSF, 2019).

\section{Evaluation}

\section{7 course evaluation}

The first iteration of this course was implemented in April 2017. Of the 78 students that enrolled, a majority (98\%) were from the School of Pharmacy (Table II). In 2017, the average rating across speakers was 8.0 (range: 8.7-9.4) on a 10-point scale. All enrolled students completed the course evaluations and provided favourable ratings (Table III). Four themes were identified from students' course evaluation comments: Speakers Representing Diverse Perspectives, Important and Applicable Course Topics, Integrate Actionable Examples, and Improve
Coordination Across Speakers (Table IV). Many students mentioned the session topics were informative, applicable, and relevant. Students stated they enjoyed learning from speakers representing diverse backgrounds as educators, healthcare providers, and activists. Students also provided constructive feedback, such as improving coordination across speakers to avoid presentation of repetitive information and identifying more ways for health professional students to address climate health issues.

Table II: Demographics by course year

\begin{tabular}{lccc}
\hline \multicolumn{1}{c}{ Programme } & $\begin{array}{c}\mathbf{2 0 1 7} \\
\text { enrollees } \\
\mathbf{n = 7 8 ( \% )}\end{array}$ & $\begin{array}{c}\mathbf{2 0 1 8} \\
\text { enrollees } \\
\mathbf{n = 6 5 ( \% )}\end{array}$ & $\begin{array}{c}\mathbf{2 0 1 9} \\
\text { enrollees } \\
\mathbf{n = 9}(\%)\end{array}$ \\
\hline $\begin{array}{l}\text { School of } \\
\text { Pharmacy }\end{array}$ & $76(98)$ & $65(100)$ & $6(67)$ \\
\hline School of Nursing & $1(1)$ & $0(0)$ & $3(33)$ \\
\hline $\begin{array}{l}\text { School of } \\
\text { Medicine }\end{array}$ & $1(1)$ & $0(0)$ & $0(0)$ \\
\hline $\begin{array}{l}\text { School of } \\
\text { Dentistry }\end{array}$ & $0(0)$ & $0(0)$ & $0(0)$ \\
\hline $\begin{array}{l}\text { School of Physical } \\
\text { Therapy }\end{array}$ & $0(0)$ & $0(0)$ & $0(0)$ \\
\hline $\begin{array}{l}\text { Graduation } \\
\text { division } \\
\text { programmes }\end{array}$ & $0(0)$ & $0(0)$ & $0(0)$ \\
\hline
\end{tabular}

Table III: Annual course evaluation ratings by students

\begin{tabular}{lccc}
\hline & $\begin{array}{c}\mathbf{2 0 1 7} \\
\text { course } \\
(\mathrm{n}=78) \\
\text { Mean (SD) }\end{array}$ & $\begin{array}{c}\mathbf{2 0 1 8} \\
\text { course } \\
(\mathrm{n}=60) \\
\text { Mean (SD) }\end{array}$ & $\begin{array}{c}\mathbf{2 0 1 9} \\
\text { course } \\
(\mathrm{n}=6) \\
\text { Mean (SD) }\end{array}$ \\
\hline $\begin{array}{l}\text { Course was well- } \\
\text { organised }\end{array}$ & $4.33(0.59)$ & $4.35(0.80)$ & $4.5(0.84)$ \\
\hline $\begin{array}{l}\text { Student } \\
\text { participation and } \\
\text { interaction with } \\
\text { instructor(s) }\end{array}$ & $4.19(0.76)$ & $4.33(0.82)$ & $4.67(0.52)$ \\
\hline $\begin{array}{l}\text { Course lectures, } \\
\text { activities, and } \\
\text { assignments helped } \\
\text { me to learn the } \\
\text { material }\end{array}$ & $4.09(0.86)$ & $4.35(0.73)$ & $4.67(0.52)$ \\
\hline
\end{tabular}

\section{8 course evaluation}

Based on 2017 course feedback, most speakers were retained (Table I). Two speakers with expertise in hydraulic fracturing and environmental and respiratory health were also recruited to present in 2018. Speakers were encouraged to incorporate more active learning and examples of advocacy efforts or opportunities for student engagement. In an attempt to decrease repetition across sessions, each speaker received a copy of the course syllabus and was encouraged to review the list of speakers and topics. In 2018, a total 
of 65 students enrolled, who all represented the School of Pharmacy (Table II). The average rating across speakers was 9.4 (range: 8.7-9.7) on a 10-point scale. Course ratings showed similar student agreement with course organisation and slightly improved ratings for instructor interactions/students participation and course materials compared to the prior year (Table III). Similar themes were identified from student course evaluation comments (Table IV). Students commented on the effectiveness of inviting speakers from various backgrounds who shared their knowledge and efforts to address climate change and health. Students again requested that speakers identify areas for student involvement in climate change efforts. Students did not mention overlap or repetition in the lectures, but they suggested improvements to the course administration by providing the presentation slides to the students and incorporating more time for questions and group discussions to promote student participation.

Table IV: Qualitative themes and representative student quotes identified in course evaluations by year

\begin{tabular}{|c|c|c|}
\hline 2017 Course & 2018 Course & 2019 Course \\
\hline Speakers representing diverse perspectives: & Speakers representing diverse perspectives: & $\begin{array}{l}\text { Speakers representing } \\
\text { diverse perspectives: }\end{array}$ \\
\hline $\begin{array}{c}\text { "...having a variety of speakers from different } \\
\text { backgrounds gave us multiple perspectives of Earth } \\
\text { Health" }\end{array}$ & $\begin{array}{c}\text { "...continue having speakers from different } \\
\text { departments and institutions sharing their } \\
\text { knowledge about climate change and their efforts to } \\
\text { change policies and practices." }\end{array}$ & \multirow{5}{*}{$\begin{array}{c}\text { "Great speakers. All of } \\
\text { them had a unique } \\
\text { message about climate } \\
\text { change and our impacts } \\
\text { on it..." }\end{array}$} \\
\hline $\begin{array}{c}\text { "I enjoyed learning from different health care } \\
\text { workers...involved in educating the public about } \\
\text { climate change and seeing the various ways they are } \\
\text { making an impact" }\end{array}$ & $\begin{array}{c}\text { "I enjoyed hearing from different health professionals } \\
\text { and their personal activity and engagement in } \\
\text { environmental health." }\end{array}$ & \\
\hline Important and applicable course topics: & Important and applicable course topics: & \\
\hline $\begin{array}{c}\text { "...very important and relevant topic for us to } \\
\text { understand... increasing my awareness of climate and } \\
\text { its impact on health" }\end{array}$ & $\begin{array}{c}\text { "...teaches students very important information } \\
\text { about [the] environment and what health } \\
\text { professionals can do about it" }\end{array}$ & \\
\hline $\begin{array}{c}\text { "...covered a great array of topics focused around } \\
\text { environmental factors that affect public health. I } \\
\text { think it is useful knowledge for every health } \\
\text { professional..." }\end{array}$ & $\begin{array}{l}\text { "I really enjoyed the diversity of topics that we were } \\
\text { exposed to, as well as sustainable practices we can } \\
\text { incorporate in our daily lives." }\end{array}$ & \\
\hline Integrate actionable examples & Integrate actionable examples & \multirow{5}{*}{$\begin{array}{l}\text { Changes for course } \\
\text { administration: } \\
\text { "...just want an added } \\
\text { speaker to talk about the } \\
\text { impacts of plastic and } \\
\text { how we could better } \\
\text { utilize it in an Earth- } \\
\text { friendly way/how we can } \\
\text { model our lifestyles going } \\
\text { forward around using it" }\end{array}$} \\
\hline $\begin{array}{l}\text { "I found this course.... a little disheartening. I wish } \\
\text { there was more of a focus on what we personally can } \\
\text { do to help from an individual and policy standpoint" } \\
\text { "I was truly interested in learning about how health } \\
\text { care professionals can make an impact on earth } \\
\text { health; however, only one lecture...addressed this } \\
\text { topic directly" }\end{array}$ & $\begin{array}{c}\text { "What I would have liked to see more of though was } \\
\text { how they [the speakers] actually got into the path } \\
\text { they were on, and how we as students could engage } \\
\text { more before we graduate..." } \\
\text { "I believe it would have been engaging if we actually } \\
\text { did something for the community with our new } \\
\text { source of knowledge." }\end{array}$ & \\
\hline Improve coordination across speakers: & Changes for course administration: & \\
\hline $\begin{array}{l}\text { "Some of the information became repetitive as the } \\
\text { course went on... it is hard for them [speakers] to } \\
\text { know what information was presented before them" }\end{array}$ & $\begin{array}{c}\text { "I would have liked to have the powerpoints for } \\
\text { reference" }\end{array}$ & \\
\hline $\begin{array}{c}\text { "It seemed to me like there was a lot of overlap in the } \\
\text { lectures we heard." }\end{array}$ & $\begin{array}{l}\text { "I would like to see more student discussions being } \\
\text { incorporated...]" }\end{array}$ & \\
\hline
\end{tabular}

\section{9 course evaluation}

After reviewing the 2018 student evaluations and acknowledging the growing urgency for climate action with current events, the course instructors added a second session on activism from a clinician's perspective in 2019 (Table I). With each speakers' permission, the presentation slides were shared with the students each week. Only nine students enrolled in the course due to changes in elective requirements in the School of Pharmacy and scheduling conflicts with 
the School of Medicine. Enrolled students represented both the Schools of Pharmacy $(n=6)$ and Nursing $(n=3)$ (Table II). The mean rating across speakers was 9.3 (range: $8.8-10$ ) on a 10.0 scale. Course ratings improved ratings across all domains compared to the prior years (Table III). Only two students provided course evaluation comments. These students mentioned the diversity of speakers but also suggested including a speaker in the future who could comment on the impacts of and mitigation strategies for plastic.

\section{Future plans}

A 10-week elective course on climate change and health, designed by students and supported by faculty, resulted in favourable evaluations among health professions students. Based on the student feedback, two strengths have been identified. First, the involvement of passionate, interdisciplinary clinical role models and environmental advocates provided a range of perspectives that piqued students' interest and engagement. Second, students appreciated the importance and relevance of these topics for both their personal lives and future professional careers.

Several limitations prevent the evaluation of robust student learning outcomes at this time. Despite the initial favourable enrollment, only nine students enrolled in the course during 2019. The UCSF School of Pharmacy reduced the required elective unit requirements in 2018, which may have led to the observed reduction in student enrollment. The authors also noted that students largely represented the School of Pharmacy. Since the CNI fellows advertised the elective course by posting flyers and delivering announcements in all the health professions classes, the authors suspect the reduced enrollment may have resulted from conflicting student schedules in other health professions schools. This lack of representation across professions limits the ability to assess the achievement of interprofessional competencies at this time.

To address these limitations, the authors plan to coordinate across the UCSF health professions schools to identify a mutually agreeable time to offer the course in the future. The authors are also exploring cocurricular opportunities to provide students with a path towards mitigating climate change. One way the authors may achieve this goal is by collaborating with an interdisciplinary student organisation at UCSF called Human Health and Climate Change (HHCC). Two CNI Fellows from the Schools of Pharmacy and Medicine and two medical students created HHCC to educate health professions students about climate change and promote activism through training and networking opportunities. HHCC joins several student climate change groups from around the world via the Planetary Health Next Generation Network, which supports global student partnerships centred on education and research. Through these efforts, HHCC aims to educate health professions students and facilitate involvement with climate action organisations.

Once course enrollment recovers and represents students from all health professions schools, the authors plan to conduct an assessment of student learning outcomes. This course aims to enhance knowledge about climate change, shape attitudes, and promote sustainability behaviours within one's professional practice. The authors plan to measure student knowledge by conducting pre-/postassessments on topics addressed in the course objectives. The authors also plan to evaluate the extent to which this course shaped attitudes and the application of sustainability within students' careers by conducting delayed assessments of students' attitudes and behaviours.

\section{Acknowledgements}

The authors acknowledge the following individuals for their teaching contributions to the Earth Health course: Dr. Homer Boushey, Dr. Annemarie Donjacour, Dr. Robert Gould, Dr. Katherine Gundling, Catherine Harrison, Dr. Peter Joseph, Gail Lee, Dr. Preston Maring, Dr. Michael Martin, Dr. Jeff Ritterman, Dr. Linda Rudolph, Dr. Ted Schettler, Dr. Seth Shonkoff, Dr. Neeta Thakur, and Dr. Mary Williams.

\section{Conflicts of interest}

None

\section{Funding and support}

This work was supported by grants from the UCSF Carbon Neutrality Initiative Fund

\section{References}

Cook, C., Demorest, S., \& Schenk, E. (2019). Nurses and Climate Action. The American Journal of Nursing, 119(4), 5460. https://doi.org/10.1097/01.NAJ.0000554551.46769.49

Crimmins, A., Balbus, J., Gamble, J. L., Beard, C. B., Bell, J. E., Dodgen, D., Eisen, R. J., Fann, N., Hawkins, M. D., Herring, S. 
C., Jantarasami, L., Mills, D. M., Saha, S., Sarofim, M. C., Trtanj, J., \& Ziska, L. (2016). The Impacts of Climate Change on Human Health in the United States: A Scientific Assessment. U.S. Global Change Research Program. https://doi.org/10.7930/JOR49NQX

Gruenberg, K., Apollonio, D., MacDougall, C., \& Brock, T. (2017). Sustainable Pharmacy: Piloting a Session on Pharmaceuticals, Climate Change, and Sustainability within a U.S. Pharmacy Curriculum. INNOVATIONS in Pharmacy, 8(4), 3. https://doi.org/10.24926/iip.v8i4.929

International Pharmaceutical Federation. (2016). FIP Statement of Policy- Environmentally Sustainable Pharmacy Practice: Green Pharmacy. The Hague, The Netherlands. Available at: https://www.fip.org/file/1535

Leffers, J., Levy, R. M., Nicholas, P. K., \& Sweeney, C. F. (2017). Mandate for the Nursing Profession to Address Climate Change Through Nursing Education. Journal of Nursing Scholarship, 49(6), 679-687. https://doi.org/10.1111/jnu.12331

Levy, B. S., \& Patz, J. A. (2015). Climate Change, Human Rights, and Social Justice. Annals of Global Health, 81(3), 310-322. https://doi.org/10.1016/j.aogh.2015.08.008

Mercer, C. (2019). Medical Students Call for More Education on Climate Change. Canadian Medical Association Journal, 191(10), E291-E292. https://doi.org/10.1503/cmaj.1095717

Richardson, J., Grose, J., Doman, M., \& Kelsey, J. (2014). The use of evidence-informed sustainability scenarios in the nursing curriculum: Development and evaluation of teaching methods. Nurse Education Today, 34(4), 490-493. https://doi.org/10.1016/j.nedt.2013.07.007

Shaman, J., \& Knowlton, K. (2018). The Need for Climate and Health Education. American Journal of Public Health, 108(S2), S66-S67. https://doi.org/10.2105/AJPH.2017.304045

Teherani, A., Nishimura, H., Apatira, L., Newman, T., \& Ryan, S. (2018). Identification of core objectives for teaching sustainable healthcare education. Medical Education Online, 22(1), Article 1386042. https://doi.org/10.1080/10872981.2017.1386042

UCSF. (2019). Quality Improvement (QI) and Quality Assurance (QA). Available at: https://irb.ucsf.edu/qualityimprovement-qi-and-quality-assurance-qa

Watts, N., Amann, M., Arnell, N., Ayeb-Karlsson, S., Belesova, K., Boykoff, M., Byass, P., Cai, W., Campbell-Lendrum, D., Capstick, S., Chambers, J., Dalin, C., Daly, M., Dasandi, N., Davies, M., Drummond, P., Dubrow, R., Ebi, K. L., Eckelman, M., ... Montgomery, H. (2019). The 2019 report of The Lancet Countdown on health and climate change: Ensuring that the health of a child born today is not defined by a changing climate. Lancet (London, England), 394(10211), 1836-1878. https://doi.org/10.1016/S0140-6736(19)32596-6 